\title{
Determination of Proper Gamma Radiation Doses in Sunflower Varieties
}

\author{
Sevil Yalcin (Corresponding author) \\ Canakkale Onsekiz Mart University, Education Faculty, \\ Mathematics and Science Education Department, Biology Education, Canakkale, Turkey \\ E-mail: sevilyalcin@comu.edu.tr \\ Gulruh Ulakoglu \\ Istanbul University, Faculty of Science, Department of Biology, Istanbul, Turkey \\ E-mail:g_ulakoglu@gmail.com
}

\begin{abstract}
In this study, different gamma radiation doses were applied to two sunflower varieties seeds to determine their effects on some plant characteristics in plants and to determine $\mathrm{GR}_{50}$ doses for effective mutation dose values in mutation breeding studies. The effect of gamma irradiation on the germination percentage and seedling height $(\mathrm{cm})$ of two sunflower varieties were investigated at different doses $(0,50,100,150$, 200, 250, 300, 400 and $500 \mathrm{~Gy}$ ). Gamma radiation was applied to seeds from Cesium-137 ( ${ }^{137} \mathrm{Cs}$ ) source. The trial was conducted as a split-plot experimental design in three replications. As a result, germination percentages of sunflower varieties were not affected with increasing radiation doses. But, as parallel to increasing doses applied of gamma radiation dose seedling height $(\mathrm{cm})$ were affected negatively. On the other hand, the doses that decrease growth by 50 percent $\left(\mathrm{GR}_{50}\right)$ for AS508 and Nantio were found to be 148 Gy and 165 Gy, respectively.
\end{abstract}

Keywords: Helianthus annuus $\mathrm{L}, \mathrm{GR}_{50}$ dose, $\mathrm{M}_{1}$ plants.

DOI: $10.7176 / \mathrm{JSTR} / 5-9-04$

Bu çalışma "Gama Radyasyonu ile Işınlanmış Ayçiçeği (Helianthus annuus L.) Çeşitlerinin Üzerine Manyetik Alanın Etkisi" isimli doktora tez çalışmasının bir bölümünden alınmıştır.

\section{Ayçiçeği Çeşitlerinde Uygun Gama Radyasyon Dozlarının Belirlenmesi}

Özet

$\mathrm{Bu}$ çalışma AS508 ve Nantio ayçiçeği tohumlarına uygulanan farklı gama radyasyon dozlarının $\mathrm{M}_{1}$ bitkilerinde bazı özellikler üzerine etkilerinin belirlenmesi ve mutasyon islah çalışmalarında kullanılabilecek \% 50 büyümeyi azaltan doz $\left(\mathrm{GR}_{50}\right)$ değerini saptamak amacıyla yapılmıştır. AS508 ve Nantio ayçiçeği çeşidinin tohumlarına farklı dozda $(0,50,100,150,200,250,300,400$ ve 500 Gy ) gama radyasyonu uygulanarak $\mathrm{M}_{1}$ bitkilerinde çimlenme yüzdesi, fide boyu $(\mathrm{cm})$ üzerine etkisi incelenmiştir. Tohumlara gama radyasyonu Sezyum-137 $\left({ }^{137} \mathrm{Cs}\right)$ kaynağından uygulanmıştır. Deneme bölünmüş parseller deneme deseninde 3 tekerrürlü olarak yürütülmüştür. Sonuç olarak, artan gama radyasyon dozlarının ayçiçeği çeşitlerinin çimlenme yüzdesi üzerine etkisinin olmadığı saptanmıştır. Ancak artan doz uygulamasına paralel olarak fide bitki boyunu olumsuz etkilemiştir. Diğer taraftan fide boyunu \%50 azaltan doz $\left(\mathrm{GR}_{50}\right)$, AS508 için 148 Gy ve Nantio için 165 Gy olarak bulunmuştur.

Anahtar Kelimeler: Helianthus annuus L, GR ${ }_{50}$ dozu, $\mathrm{M}_{1}$ bitkileri. 


\section{Giriş}

Ayçiçeği (Helianthusannuus L., 2n = 34) Asteraceae ailesine ait bir kültür bitkisi olup, anavatanı Güney Amerika ve Meksika'dır. Günümüzde, ayçiçeği, hurma, soya fasulyesi ve kolza tohumu ile birlikte dünyada kolzadan sonra dördüncü en önemli yağlı tohum bitkisidir (Girishraj,2013). Türkiye'de yağ endüstrisi genelde ayçiçeği ve zeytine dayalı olmasından dolayı ihtiyacı karşılayamamakta olup yağ açığını kapatmak için alternatif yağlı tohumlu bitkilerin üretimi önem kazanmıştır. Ülkemizde de birçok alanda kullanım amaçlı olarak genelde bitkisel yağ olarak ayçiçeği yağı tüketildiğinden, ülkemiz için ayçiçeği önemli bir katma değer kaynağıdır (Kaya,2013). Bu duruma bağlı olarak kaliteli ve verimli yağ eldesi sağlayacak metodların zenginleştirilmesi de oldukça önemlidir. Tüm kültür bitkilerinde olduğu gibi ayçiçeğinin birim alan verimine, başta genotipik özellikler olmak üzere, ekolojik faktörler ve tarımsal uygulamalar da etki etmektedir (Baydar, 2000). Bu nedenle, bitkilerde çeşitliliğin artırılmasında klasik ıslah yöntemlerine alternatif olarak mutasyon ıslahı yöntemi kullanılmaktadır. Mutasyon, bitki 1slahı için klasik ıslah yöntemlerine alternatif olabilen bir yöntem olmakla birlikte, kimyasal veya fiziksel mutajenler kullanılarak genetik materyalde değişimlere sebep olan işlem olarak tanımlanmaktadır (Krupa-Malkiewicz ve ark., 2017). Mutajenlerin kullanımı, birçok bitkide kalitatif ve kantitatif özellikleri 1slah etmede kullanılan hızlı ve etkin bir metottur (Gerami ve ark., 2017).

Bitki mutasyon ıslahı çalışmalarında, özellikle son 20 yıl içerisinde elde edilen sonuçlar, mutasyonlardan yararlanma olanaklarının oldukça fazlalaştığını göstermektedir. Yapılan araştırmalar sonucu fiziksel bir mutajen olan gama radyasyon ile birçok bitkide mutant bireyler geliştirilmiştir (Vaizoğulları,2016; Çoban ve ark.,2017; Gaafar ve ark., 2017). Ancak mutasyon oluşturmak amacı ile uygulanan radyasyon; düşük mutasyon frekansı meydana getirebildiği gibi bitkisel materyalde ışıllamanın dozuna bağlı olarak, bitki gelişmesinde yavaşlatma, pigment kaybı, protein içeriğinde azalma, sterilite gibi yüksek mutasyon frekansı ve düşük fizyolojik zarar da meydana getirebilir. Radyasyona karşı her bitki türünün duyarlılığı farklı olup, bu farklılık ışınlama ortamının sıcaklığına, ışınlamanın oksijenli veya oksijensiz bir ortamda yapılmasına, ışınlanacak materyalin su içeriği gibi çevresel faktörlere bağlı olduğu gibi, aynı zamanda 1şınlanacak türler arasındaki biyolojik faktörlere bağlıdır (Peşkircioğlu, 1996; Shu ve ark. 2012; Çelik ve Atak 2017).

Genellikle çeşitli bitki kısımlarının radyasyona karşı duyarlılığı da farklıdır ve ışınlanacak bitki kısımları amaca göre değişmektedir. Işınlamalarda en çok tercih edilen materyal tohumlardır. Çünkü tohumlar 1slatılabilen, kurutulabilen, dondurulabilen ve 1sitılabilen bir materyal olması ve normalde canlı moleküllerin dayanamayacağı fiziksel koşullarda bile ışınlanabilme özelliğinden dolayı mutasyon çalışmalarında en çok kullanılan materyaldir (Ali ve ark., 2016; Oladosu ve ark., 2016).

Mutasyon çalışmalarında fiziksel ve kimyasal mutajen uygulamalarında en uygun mutajen dozunun belirlenmesi çok önemlidir. Radyasyonun zararlı etkilerinin kullanılan bitkilere ve mutajenlerin cinsine bağlı olarak değiştiği, mutajenin dozunun yükselmesine bağlı olarak zararlanmanın arttığ1, çeşitli araştırmacılar tarafından ortaya konmuştur (Bağcı ve Mutlu, 2014; Yazıcı ve ark. 2016). Fiziksel ve kimyasal mutajenler genellikle fiziksel zararlanmaları, gen mutasyonlarını ve kromozom mutasyonlarını meydana getirmektedir. Radyasyonun meydana getirdiği fizyolojik zarar $\mathrm{M}_{1}$ neslinde ortaya çıkmaktadır. Ancak diğer nesillere aktarılmaz. Bitkilerde görülen fizyolojik bozukluklar arasında, çimlenme gecikmesi (Ulukapı ve ark., 2015), bitki çıkışında gecikme ya da azalma, büyümede gerileme, klorofil eksiklikleri (Marcu ve ark.,2013a; Sikder ve ark. 2013; Rozman, 2014), sitolojik (mitotik indeks ve kromozomal sapmalar) (Girija ve ark.,2013) ve biyokimyasal (şeker, karbon, protein, prolin vb içerikleri) (Datta ve ark..2011; Louali ve ark.,2015) gibi zararlar sayılabilir. Fizyolojik zarar, kromozomal ve kromozom dışı nedenler ile ortaya çıkabilir ve artan radyasyon dozu, fizyolojik zararın miktarını da artırır (Gaul,1977).

Bitkilerin geliştirilmesinde amaca uygun genetik etkiye sahip uygulamalar tercih edilirken, mümkün olduğu kadar az fizyolojik zararlanma; buna karşılık yüksek oranda genetik varyasyon yaratması beklenmektedir. Dozun artması ile bunların ikisi de artmakta, sonuçta bitki yaşamını sürdürememektedir. Yüksek radyasyon dozlarında bitki yaşasa bile döl verememektedir. Bu nedenle doz sınırları iyi belirlenmelidir ve bunun için de $\mathrm{GR}_{50}$ kavramı ortaya atılmıştır. Bu değer, genellikle fide yüksekliğini kontrole göre \% 50 azaltan mutajen dozdur ve her bitki türü için farklı olup, mutasyon ıslah çalışmalarına başlamadan önce belirlenmelidir. Bitki ıslah çalışmaları için optimum doz sınırları olarak GR $_{50}$ dozunun alt sınırları önerilmektedir. Bitkilere uygulanan mutajenik muamelelerde, $\mathrm{M}_{1}$ 'deki fide yüksekliği ve hayatta kalma gibi fizyolojik etkiler ile $\mathrm{M}_{1}$ mutasyon frekansı arasında bir korelasyon vardır. Bu nedenle mutasyon çalışmalarında, $\mathrm{M}_{1}$ 'deki fide zararının belirlenmesi önemlidir. Nitekim mutajenlerin bitkiler üzerindeki etkisini belirlemek amacı ile yapılan araştırmalarda, araştırıcılar fide yüksekliğini kriter olarak 
ele almışlardır (Çelik ve Atak 2017; Gaul,1977). Bu araştırmada, iki farklı ayçiçeği tohumlarına uygulanan gama radyasyon dozlarının bu çeşitlerin ilk gelişme dönemlerindeki tepkileri ile $\mathrm{GR}_{50}$ dozlarının belirlenmesi amaçlanmıştır.

\section{Materyal ve Yöntem}

Araştırmada sağlam ve normal irilikte \% 6-7 nem içeren iki farklı ayçiçeği çeşidi olan AS 508 ve Nantio tohumları bitki materyal olarak kullanılmıştır. Çeşitlere ait bu tohumlar Türkiye Şeker Fabrikaları AŞ. Lüleburgaz Sarmısaklı Tarım İşletmelerinden temin edilmiştir. Çalışmada tohumlara 0, 50, 100, 150, 200, $250,300,400$ ve 500 Gray gama radyasyon dozları İstanbul Üniversitesi, Bizim Lösemili Çocuklar Vakfi'nda bulunan Sezyum-137 ( ${ }^{137} \mathrm{Cs}$ ) IBL 437 C kaynağı (doz hızı/dakika 10 Gy) kullanılarak uygulanmıştır. Gama radyasyon uygulaması için her doz ve kontrol grubu için 100'er adet tohum polietilen torbalara konulmuş ve ışınlanmıştır. Işınlanmış olan tohumlar içinde toprak bulunan plastik kasalara bölünmüş parseller deneme desenine göre üç tekerrürlü ekilmiş ve çalışma kontrollü koşulların sağlandığı serada yürütülmüştür. Sıraya ekimin uygulandığı bu çalışmada tohumların çıkıştan itibaren 10 gün süre ile her gün çimlenme sayıları alınarak çimlenme yüzdeleri saptanmıştır.

Ayçiçeği fidelerinin birinci gerçek yapraklarındaki gelişmenin durduğu 14. günde gama radyasyonun etkisi araştırılmıştır. Her bir muameledeki fidelerin $\mathrm{GR}_{50}$ (fide boyunu \% 50 azaltan doz) dozlarının belirlenmesi için toprak yüzeyinden itibaren fide yükseklikleri tespit edilmiştir.

Elde edilen verilerin istatistik değerlendirmeleri Ege Üniversitesi, Ziraat Fakültesi Tarla Bitkileri Bölümü tarafindan hazırlanan TARIST bilgisayar programına göre lineer regresyon analizi kullanılarak yapılmış (Düzgünes ve ark.,1987) ve $\mathrm{GR}_{50}$ dozu hesaplanmıştır.

\section{Bulgular ve Tartışma}

Bu çalı̧̧mada $0,50,100,150,200,250,300,400$ ve 500 Gy dozlarında gama radyasyon ile ışınlanmış AS 508 ve Nantio çeşitlerinin tohumlarının çimlenme yüzdesi üzerine gama radyasyonun etkisi Şekil 1 'de verilmiştir.

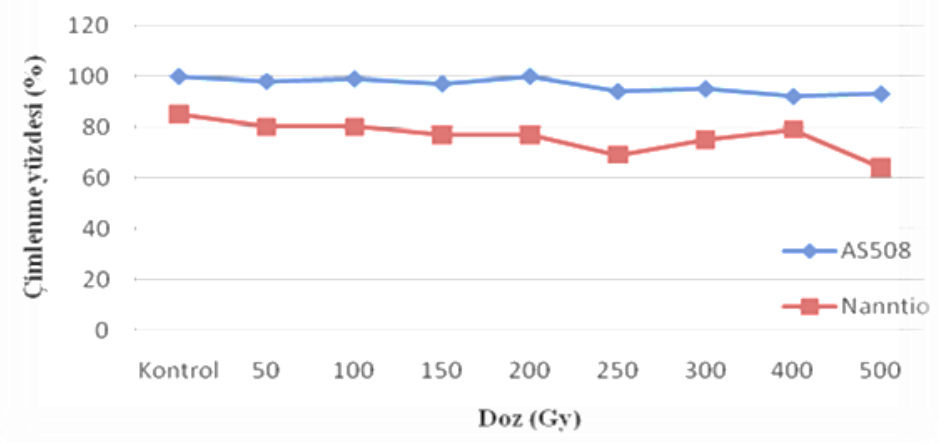

Şekill. Ayçiçeği çeşitleri tohumlarının çimlenme yüzdeleri üzerine gama radyasyonun etkisi

Gama radyasyonun AS 508 ayçiçeği bitkisinin tohumlarının çimlenmesi üzerinde belirgin bir etkisinin olmadığ ancak Nantio çeşidinde kontrole göre artan dozlarda bir azalmanın olduğu gözlenmiştir. $\mathrm{Bu}$ çalışmada bulunan sonuca benzerlik gösteren bir araştırmada, Bhosale ve More (2014) uygulanan farklı radyasyon dozlarında kişniş (Coriandrumsativum L.) bitki tohumlarının çimlenme yüzdesinde kontrole göre en fazla azalmanın 700 Gy'lik radyasyon dozunda olduğunu rapor etmişlerdir. Bu konuya benzerlik gösteren diğer bitki çeşitlerinden elde edilen başka çalışmalar da mevcuttur (Sikder ve ark., 2013; Bharathive ark., 2013; Ariraman ve ark., 2018).

Tohumlara uygulanan gama radyasyon tunika tabakasının bozulması ve dağılması ile tohum çimlenmesinin engellenmesine yol açmaktadır (Chauhan ve Singh,1975). Bunun yanısıra radyasyon, enzim aktivitesi ve hücre bileşenlerinin zarar görmesine de yol açabilir (Khan ve Goyal, 2009).Micco ve ark.(2011) radyasyonun, tohum çimlenmesini mitotik döngülerde ve hücrenin biyo-fizyolojik metabolik yollarını olumsuz yönde etkileyebildiğini ortaya koymuşlardır. Ayrıca, mutajenik uygulamalar, DNA zincir kırılmalarına ve DNA sentezinde inhibisyona yol açarak, tohum çimlenmesini azaltabilir (Gaur ve ark., 2018).

Çimlenme ve hayatta kalma oranındaki azalma, radyasyonun doğrudan hücredeki kritik hedeflere etki

27 I P a g e

www.iiste.org 
eden biyolojik materyallerde absorbe edilmesinden kaynaklanabilir (Kovacs ve Keresztes 2002). Bashir ve ark. (2013) ayrıca tohum çimlenme ve hayatta kalma yüzdesindeki azalmanın, dozdaki ve mutajen konsantrasyonundaki artış ile azaldığını bildirmişlerdir. Mutajenlerin daha düşük muamele edilmesinin daha az biyolojik hasarı etkilediği ve istenen mutasyonları uyarmak için uygun olacağı sonucuna vardılar. Ayrıca daha düşük miktarda mutajen uygulamasının daha az biyolojik hasar oluşturabileceğini ve istenen mutasyonları teşvik etmek için uygun olacağ 1 sonucunu ortaya koymuşlardır. Bu konuda yapılan çalışmalar, yüksek gama radyasyon dozlarının, rezene (Verma ve ark., 2017), ayçiçeği (Diaz ve ark. 2018) ve kişnişteki çimlenme yüzdesini ve hayatta kalma oranını azalttığını destekler niteliktedir (Sarada ve ark., 2015). Radyasyonunçimlenmeyüzdesiüzerinegeneldebiretkisininolmadığınıösterençalışmalar da mevcuttur (Antunez-Ocampo ve ark.,2017; Hussainveark. 2017; Gordeevaveark. 2018).

Bitkilerin radyasyona karşı verdikleri cevapları en iyi gösteren parametrelerden biri de fide boyunun ölçülmesidir. Bu nedenle radyobiyolojik çalışmalarda fide yüksekliğginin belirlenmesi önemlidir (Shu ve ark.,2012; Sikder ve ark. 2013). Gama radyasyonun fide yüksekliği üzerine etkisini belirlemek amaciyla kontrol ve ışınlanmış 100 adet tohumdan yetiştirilen fidelerin yükseklikleri ölçülmüş ve ilgili veriler Tablo 1 ve Şekil 2'de verilmiştir.

Tablo 1. AS 508 ve Nantio ayçiçeği çeşitlerinde gama radyasyonun14. gündeki fide yüksekliği üzerine etkisi

\begin{tabular}{|c|c|c|c|c|c|c|c|}
\hline Çeşit & $\begin{array}{l}\text { Doz } \\
\text { (Gy) }\end{array}$ & $\begin{array}{l}\text { Fide sayis1 } \\
\text { (adet) }\end{array}$ & $\begin{array}{l}\text { Fide Yüksekliği } \\
(\mathrm{cm})\end{array}$ & Çeşit & $\begin{array}{l}\text { Doz } \\
\text { (Gy) }\end{array}$ & $\begin{array}{l}\text { Fide say1s1 } \\
\text { (adet) }\end{array}$ & $\begin{array}{l}\text { Fide Yüksekliği } \\
(\mathrm{cm})\end{array}$ \\
\hline \multirow{9}{*}{$\begin{array}{l}\infty \\
0 \\
0 \\
2 \\
2\end{array}$} & Kontrol & 98 & $12.37 \pm 0.41$ & \multirow{9}{*}{ 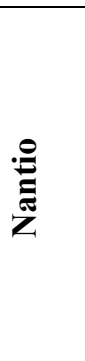 } & Kontrol & 92 & $11.72 \pm 0.78$ \\
\hline & 50 & 96 & $11.14 \pm 1.51$ & & 50 & 83 & $10.46 \pm 0.75$ \\
\hline & 100 & 96 & $8.90 \pm 1.27$ & & 100 & 84 & $8.57 \pm 0.74$ \\
\hline & 150 & 97 & $5.99 \pm 0.22$ & & 150 & 84 & $6.53 \pm 0.57$ \\
\hline & 200 & 98 & $4.49 \pm 0.78$ & & 200 & 83 & $4.54 \pm 0.90$ \\
\hline & 250 & 96 & $2.92 \pm 0.46$ & & 250 & 72 & $3.60 \pm 0.63$ \\
\hline & 300 & 95 & $2.40 \pm 0.71$ & & 300 & 73 & $2.16 \pm 0.41$ \\
\hline & 400 & 94 & $2.55 \pm 0.87$ & & 400 & 73 & $2.99 \pm 0.66$ \\
\hline & 500 & 85 & $1.88 \pm 0.65$ & & 500 & 67 & $2.11 \pm 0.86$ \\
\hline
\end{tabular}

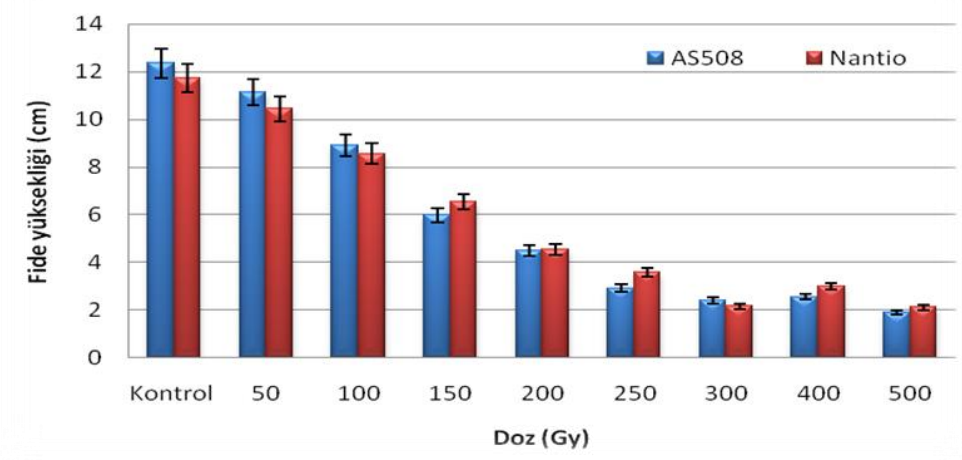

Şekil 2.Farklı gama radyasyon dozlarının AS508 ve Nantio çeşitlerinin fide yükseklikleri üzerine etkisi

Fide sayıları 14. günde saptanmış olup, kontrol grubuna göre fide sayısında AS 508 çeşidinde 500 Gy dozda bir azalma saptanmıştır. Oysa Nantio çeşidinde 50 Gy dozdan itibaren bir azalma görülmüştür. Ayçiçeği bitkisinin kontrol grubuna ait ortalama fide yükseklikleri, AS 508 çeşidi için $12.37 \pm 0.41 \mathrm{~cm}$; Nantio çeşidi için $11.72 \pm 0.78 \mathrm{~cm}$ olarak ölçülmüştür. Uygulanan radyasyon dozunun artışına paralel olarak fide yüksekliklerinde de kontrole göre azalmanın olduğu saptanmıştır (Şekil 3). Gama radyasyon dozunun artmasına paralel olarak bitki yaşamını sürdürememekte, ya da yaşasa bile üreyememektedir. Bu nedenle kullanılacak doz sınırlarının iyi belirlenmesi gerekmektedir. Bunun için fide boyunu kontrole göre \%50 azaltan $\left(\mathrm{GR}_{50}\right)$ mutajen dozunu belirlemek önemlidir.

Yapılan bu çalı̧̧ma sonucunda, AS 508 çeşidi için GR 50 dozu 148 Gy, Nantio çeşidi için 165 Gy olarak

28| P a g e

www.iiste.org 
belirlenmiştir. Bu değerler ayçiçeği çeşitleri için 100-300 Gy arasındadır (Uslu, 1996).

Diaz ve ark.(2018) ayçiçeği ile yaptıkları bir çalışmada GR 50 dozunu 500Gy olarak saptamışlardır. Farklı bitkilerde $\mathrm{GR}_{50}$ dozları da farklılık göstermektedir. Limtiyayotinve ark.(2018) ev menekşesinin invitro kültürlerine 10, 20, 30, 40, 50 ve 60 Gy'lik radyasyon dozu uygulamışlar ve GR ${ }_{50}$ dozunu 42 Gyolarak bulmuşlardır. Yine kimyon için $\mathrm{GR}_{50}$ dozu $200 \mathrm{~Gy}$ (Verma ve ark, 2017), Afrika çimeni için $\mathrm{GR}_{50}$ dozu 1357 ve 1900 Gy arasında (Alvarez-Holguin ve ark., 2018) saptanmıştır.

AS 508 ve Nantio ayçiçeği çeşitlerinin fide yükseklikleri ile gama radyasyon arasındaki ilişki regresyon eğrisi çizilerek Şekil 4'te verilmiştir.

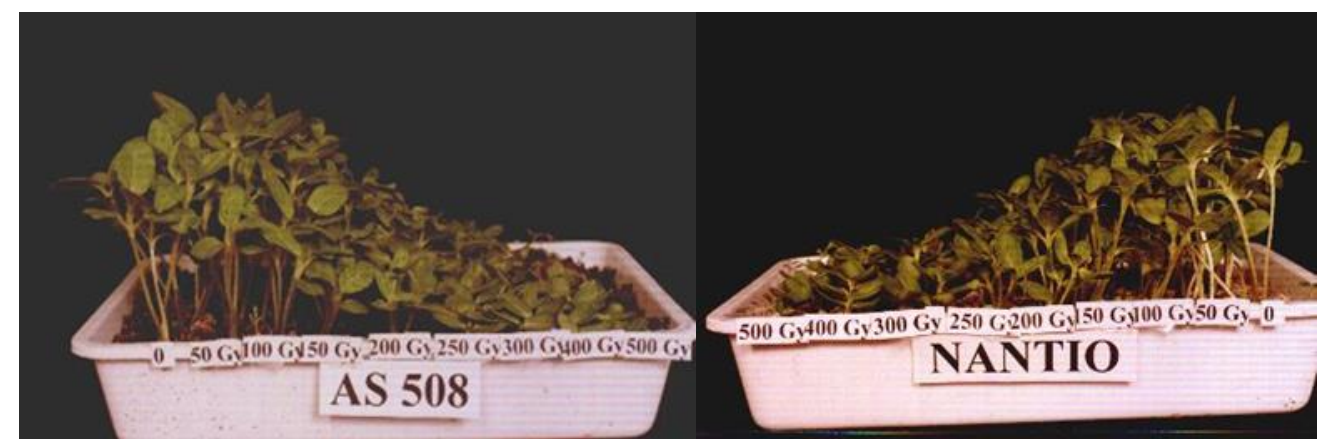

Şekil 3. İki farklı ayçiçeği çeşidinde farklı radyasyon dozlarının 14. gündeki fide yüksekliği üzerine etkisi (Genel görünüş)
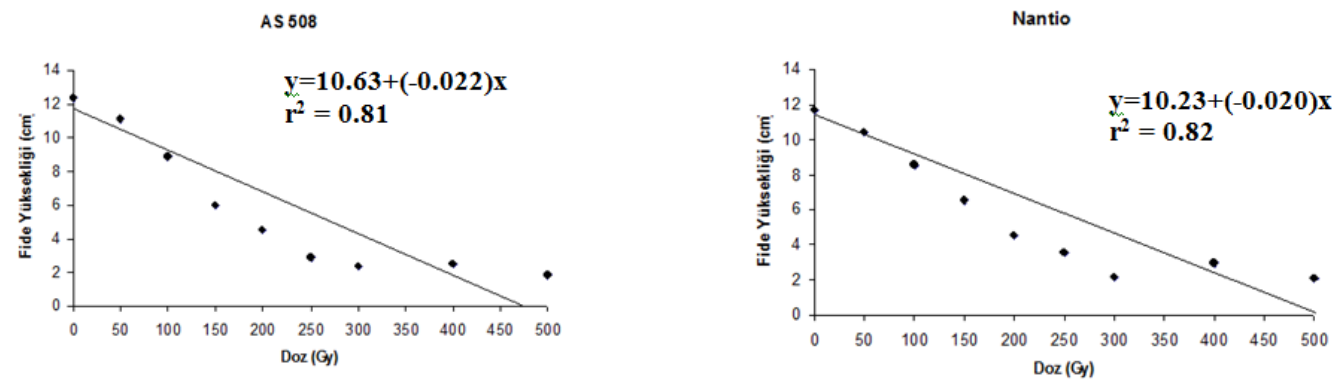

Şekil 4. AS 508 ve Nantio ayçiçeği çeşitlerinin fide yükseklikleri ile gama radyasyon arasındaki ilişki

Bu çalışmada kullanılan AS 508 ve Nantio ayçiçeği çeşitlerinde, artan radyasyon dozuna bağlı olarak fide yüksekliklerinde kontrole göre bir azalma olduğu belirlenmiştir. Elde edilen sonuçlara göre yapılan regresyon analizi sonucu, iki farklı ayçiçeğinde gama radyasyon dozlarının fide yüksekliğine etkisinin olduğu ve fide yüksekliği ile gama radyasyon dozları arasında doğrusal bir ilişki olduğu, yani fide yüksekliğindeki azalmanın radyasyon dozlarındaki değişmeden etkilendiği ve bunun önemli olduğu saptanmıştır $(\mathrm{p}<0,05)$.

Gvozdenovicve ark.(2009 )'nın ayçiçeği bitkisiyle yaptıkları bir çalışmada doz artışına paralel olarak fide boylarında belirli düşüşün olduğu ortaya konmuştur. Bezelye, buğday, pirinç gibi bitki türlerinde de artan radyasyon dozuna bağlı olarak fide yüksekliğinin azalması üzerine yapılmış çalışmalar bulunmaktadır (Majeed ve ark. 2016; Hong ve ark, 2018; Jiya ve ark., 2018). Yapılan birçok çalışmada, düşük radyasyon dozlarının genellikle bitkilerde çimlenme, büyüme ve gelişme üzerine olumlu bir etkiye neden olduğu, yüksek dozlarda ise büyüme anormallikleri, çimlenme geriliği veya radyasyona maruz kalan bitkilerin ölümüne neden olduğu tespit edilmiştir (Majeed ve ark. 2016; Kovalchuk ve ark. 2003). Farklı bitkilerde gama radyasyon muamelesinin, çimlenme ve büyüme üzerine etkisi, genellikle radyasyon dozu miktarına, maruz kalma süresine ve bitki türlerine bağlı olarak değişebilmektedir (Majeed ve ark. 2016; Marcu ve ark. 2013b). Düşük radyasyon dozları ile muamele edilen bitki hücrelerinde ya direkt genom modifikasyonuna yada hücrelerde antioksidan potansiyellerinde bir artışa neden olmasının yanısıra büyüme hormonları ile hücreler arasında daha iyi etkileşim kurulmasına yol 
açarak büyümenin artışına neden olabilir. Bütün bunlara ek olarak düşük radyasyon dozları fotosentez hızında ve bitkilerin çevredeki stres faktörleriyle baş edebilmesin de artırıcı bir rol oynar (Wi ve ark., 2007; Majeed ve ark. 2018). Buna karşıllk, yüksek radyasyon dozları ise; bitkilerde çimlenmede azalmaya ve büyüme anormalliklerine neden olur. Bunun nedeni, genomikzararlanma, hücrelerdeki suyun iyonlaşması sonucu diğer hücresel moleküllerle etkileşime girebilen ve negatif olarak etkileyen reaktif oksijen türlerinin (ROS) ve serbest radikallerin oluşumuna neden olmasıdır (Wang ve ark. 2017). Marcu ve ark. (2013a), uygulanan gama radyasyonu sonucu olarak oluşan bu serbest radikallerin proteinleri, lipitleri, enzimleri ve hücresel molekülleri etkilediğini böylelikle bu durumun büyüme anormalliklerini artırdığını belirtmişlerdir.

\section{Sonuç}

Ayçiçeği bitkisinin AS508 ve Nantio çeşitlerinde farklı gama ışını dozlarının fide çıkışı ve gelişimi üzerine etkisini belirlemek için yürütülen bu çalı̧smada; çeşitlerin gama dozlarına tepkileri farklı bulunmuştur. Uygulanan radyasyon dozunun artışına paralel olarak her iki çeşitte de fide yüksekliklerinde kontrole göre gelişiminin olumsuz etkilendiği saptanmıştır. Bitki gelişimindeki bu düşüşlerin artan doz uygulamasına paralel olarak lineer bir şekilde meydana geldiği de belirlenmiştir. $\mathrm{GR}_{50}$ dozu AS 508 çeşidi için 148 Gy, Nantio çeşidi için ise 165 Gy olarak saptanmıştr. Bu sonuçlara göre ileride yapılacak mutasyon ıslahı çalışmalarında $\mathrm{GR}_{50}$ dozu dikkate alınarak optimum doz uygulanarak etkin bir varyasyon oluşturulabileceği söylenebilir.

\section{Kaynaklar}

Ali, H.,Ghori, Z., Sheikh, S., Gul, A.(2016),"Effects of gamma radiation on crop production". In: Hakeem KR, editor. Crop Production and Global Environmental Issues. Springer International Publishing, Switzerland. pp. 27-78.

Alvarez-Holguin, A., Morales-Nieto, C. R., Avendaño-Arrazate, C. H., Santellano-Estrada, E., Melgoza-Castillo, A., Burrola-Barraza, M. E., Corrales-Lerma, R., (2018)." Median lethal dose and average growth reduction due to gamma radiation in African Grass (Eragrostislehmanniana Ness)". Ecosistemas Y RecursosAgropecuarios, 5(13): 81-88.

Antunez-Ocampo, O. M., Cruz-Izquierdo, S., Sandoval-Villa, M., Santacruz-Varela, A., MendozaOnofre, L. E., de la Cruz-Torres, E., Pena-Lomeli, A., (2017). "Induced variability in physiological characters of Physalis peruviana L. through Co-60 gamma rays applied to the seed". RevistaFitotecnia Mexicana, 40(2): 211-218.

Ariraman, M., Dhanavel, D., Seetharaman, N., Murugan, S., Ramkumar, R., (2018)." Gamma radiation influence on growth, biochemical and yield characters of Cajanuscajan(L.) Millsp". Journal of Plant Stress Physiology.

Bağc1, M., Mutlu, H., (2014). "Üç Macar fiği (ViciapannonicaCrantz.) çeşidinde farklı dozlarda gama 1̧̧ını uygulamasının $\mathrm{M}_{2}$ generasyonunda bazı bitkisel özellikleri üzerine etkileri". Tarla Bitkileri Merkez Araştırma Enstitüsü Dergisi, 23(2).

Bashir, S., Wani, A.A., Nawchoo, I.A., (2013). "Mutagenic sensitivity of gamma rays, EMS and sodium azide in Trigonellafoenum-graecum L". Science Research Reporter 3(1): 20-26.

Baydar, H., (2000). "Bitkilerde yağ sentezi, kalitesi ve kaliteyi artırmada ıslahın önemi". Türk-Koop Ekin Dergisi., 11: 50-57.

Bharathi, T., Gnanamurthy, S., DDhanavel, S. M. M. Ariraman,(2013)." Induced physical mutagenesis on seed germination, lethal dosage and morphological mutants of Ashwagandha (Withaniasomnifera (L.) Dunal)". International Journal of Advanced Research, 1(5):136-141.

Bhosale, R. S., More, A. D., (2014). "Effect of gamma radiation on seed germination, seedling height and seedling injury in Withaniasomnifera (L.) Dunal". International Journal Of Life Sciences, 2(3), 226-228. 
Chauhan, Y. S., Singh, R. P., (1975). "Morphological studies in safflower (CarthamusTinctorius Linn.) with special reference to the effect of 2, 4-D and gamma rays-I". Vegetative Shoot Apex. Radiation Botany, 15(1):69-77.

Çelik, Ö., Atak, Ç., (2017). "Applications of 1onizing radiation in mutation breeding. In: New insights on gamma rays" p.111-132

Çoban, M., Çiçek, S., Yazıcı, L., (2017)." Gama ışını (Cobalt 60) dozlarının İpek 607 pamuk (Gossypiumhirsutum L.) çeşidinin M4 popülasyonundaki etkileri". Kahramanmaraş Sütçü İmam Üniversitesi Doğa Bilimleri Dergisi, 20: 232-235.

Datta S.K., Debasis, C., Arvind, K.V.,Biresh, K.B.,(2011). "Gamma ray induced chromosomal aberrations and enzyme related defense mechanism in Allium cepaL". Caryologia. 64(4):388-397.

Diaz, L. E., García, S. A. L., Morales, R. A., Báez, R. I., Pérez, V. E., Olivar, H. A., Loeza, C. J. M., (2018)."Effect of gamma radiation of 60Co on sunflowerplants (Helianthusannuus L.)(Asteraceae), fromirradiatedachenes". ScientiaAgropecuaria, 9(3): 313-317.

Düzgüneş, O., Kesici, T., Kavuncu, O., Gürbüz, F. (1987)." Araştırma ve Deneme Metodları İstatistik Metodlar II", Ankara Üniversitesi Ziraat Fakültesi Yayınları:1021, Ders Kitabı:295, Ankara.

Gaafar, R., Elshanshory, A., Hamouda, M., Diab, R., (2017). "Effect of gamma-radiation doses of phenotypic and molecular characteristics of two Egyptian soybean varieties". Egyptian Journal of Botany, 57(1): 199-216.

Gaul, H., (1977)."Mutagen effect in the first generation after seed treatment", Manual on Mutation Breeding ( $2^{\text {rd }}$ Ed)., Technical Reports, Series 119, IAEA, Vienna, pp 87-95.

Gaur, A. K., Singh, I., Singh, S., Reddy, K. S., (2018)." Studies on effects of gamma ray doses on germination in pigeonpea [Cajanuscajan (L.) Millspaugh] under laboratory and field conditions". IJCS, 6(4), 1975-1977.

Gerami, M., Abbaspour, H., Ghasemiomran, V., Pirdashti, H., (2017)." Effects of ethyl methanesulfonate on morphological and physiological traits of plants regenerated from Stevia (Stevia rebaudianaBertoni) Calli". Applied Ecology and Environmental Research, 15 (3): 373385.

Girija, M., Gnanamurthy, S., Dhanavel, D., (2013). "Cytogenetics effect of gamma rays on root meristem cells of Vigna unguiculata (L.). Euro". J. of Exp. Bio. 3(2); 38-41.

GirishrajUrs, K. L., (2013). "Assessment of genetic variability for yield and yield attributing characters In confectionery sunflower (Helianthus annuus L.) germplasm ".Doctoral Dissertation, University of Agricultural Sciences Gkvk, Bangalore).

Gordeeva, E. I., Shoeva, O. Y., Yudina, R. S., Kukoeva, T. V., Khlestkina, E. K., (2018)." Effect of seed pre-sowing gamma-irradiation treatment in bread wheat lines differing by anthocyanin pigmentation". Cereal Research Communications, 46(1): 41-53

Gvozdenovic, S., Bado, S., Afza, R., Jocic, S., Mba, C., (2009). "Intervarietal differences in response of sunflower (Helianthus annuus L.) to different mutagenic treatments". In Proceedings of an International Joint FAO/IAEA Symposium. Vienna (pp. 358-360).

Hong, M. J., Kim, D. Y., Ahn, J. W., Kang, S. Y., Seo, Y. W., Kim, J. B., (2018). "Comparison of radiosensitivity response to acute and chronic gamma irradiation in colored wheat". Genetics and molecular biology, (AHEAD). 
Hussain, F., M. Iqbal, S.Z. Shah, M.A. Qamar, T.H. Bokhari, M. Abbas, M. Younus., (2017). "Sunflower germination and growth behavior under various gamma radiation absorbed doses". Acta Ecol. Sin., 37(1): 48-52.

Jiya, M., Olamide, F., Yusuf, D. O. A., Abdulhakeem, A., Muhammad, M. L., Zulukanaini, S. B., David, T. S., (2018). "Effects of gamma irradiation on submergence tolerance of two selected varieties of lowland rice (Oryza sativa L.)". GSC Biological and Pharmaceutical Sciences, 02(03):031-037

Kaya, Y.,(2013). "Ayçiçeği: Türkiye'nin en önemli yağ bitkisi". TÜRKTOB Türkiye Tohumcular Birliği Dergisi, 2(7):20-23.

Khan, S., Goyal, S., (2009)." Improvement of mungbean varieties through induced mutations". African Journal of Plant Science 3: 174-180.

Kovacs, E., Keresztes, A., (2002). "Effect of gamma and UV-B/C radiation on plant cells".Micron 33(2): 199- 210.

Kovalchuk, O., P. Burke, A. Arkhipov, N. Kuchma, S.J. James, I. Kovalchuk, I. Pogribny., (2003). "Genome hypermethylation in Pinus silvestris of Chernobyl-a mechanism for radiation adaptation". Mutat. Res. Fund. Mol. Mech. Mut., 529(1): 13-20

Krupa-Małkiewicz, M., Kosatka, A., Smolik, B., Sędzik, M.,(2017). "Induced mutations through EMS treatment and in vitro screening for salt tolerance plant of Petunia x atkinsiana D. Don". NotulaeBotanicaeHortiAgrobotanici, 45 (1): 190-196.

Limtiyayotin, M., Tosri, C., Sukin, N., Jompuk, P., (2018)." Effects of acute gamma irradiation on in vitro culture of exacum Affine Balf". F. Ex Regel. Agriculture And Natural Resources, 52(2): 121124

Louali, Y., Belbekri, N., Bouldjej, R., Ykhlef, N., Djekoun, A., (2015). "Effect of gamma irradiation on morphological, biochemical, physiological character and cytological studies of durum wheat mutants". Int. J. of Adv. Res. 3(10): 246 - 256.

Majeed, A., Muhammad, Z., Ullah, R., (2016). "Growth and yield response of field pea (Pisum sativum L.) to gamma irradiation stress". Plant Breed. Seed Sci., 74(2): 29-37.

Majeed, A., Muhammad, Z., Ullah, R., Ali, H., (2018). "Gamma irradiation I: Effect on germination and general growth characteristics of plants"-A Review. Pak. J. Bot, 50(6):2449-2453.

Marcu, D., Damian, G., Cosma, C., Cristea, V., (2013 a). "Gamma radiation effects on seed germination, growth and pigment content, and ESR study of induced free radicals in maize (Zea mays)".J. Bio. Phy. ,39: 625-34.

Marcu, D., V. Cristea, L. Daraban., (2013 b). "Dose dependent effects of gamma radiation on lettuce (Lactuca sativa var. capitata) seedlings". Int. J. Radiat. Biol., 89(3): 219-223

Micco, V.D., Arena, C., Dand, P., Durante, M., (2011)." Effects of sparsely and densely ionizing radiation on plants". Radiation and Environmental Biophysics 50: 1-19.

Oladosu, Y., Rafii, M.Y., Abdullah, N., Ghazali, H., Asfaliza, R., Rahim, H.A., Miah, G., Usman, M., (2016). "Principle and application of plant mutagenesis in crop improvement: A review". Biotechnology \& Biotechnological Equipment.30(1):1-16.

Peşkircioğlu, H., (1996). "Mutasyon ve radyasyonun bitki ıslahında kullanılması". Tübitak Bilim ve Teknik, 24(285):20-21. 
Rozman, L., (2014). "The effect of gamma radiation on seed germination of barley (Hordeum vulgare L.)". Acta Agr. Slov. 103:307-311.

Sarada, C., Jyothi, K.U.V., Rao, S., Reddy, P.V., (2015). "Mutagenic sensitivity of gamma rays, EMS and their combinations on germination and seedling vigour in coriander (Coriandrum sativum L)". International Journal of Advances in Pharmacy, Biology and Chemistry 4(2): 430-438.

Shu, Q. Y., Forster, B. P., Nakagawa, H.,\& Nakagawa, H., (Eds.)., (2012). Plant mutation breeding and biotechnology. $\mathrm{CABI}$.

Sikder, S., Biswas, P., Hazra, P., Akhtar, S., Chattopadhyay, A., Badigannavar, A.M. D'.,Souza, S.F., (2013)." Induction of mutation in tomato (Solanum lycopersicum L.) by gamma irradiation and EMS". Indian J. Genet. 73:392- 399.

Ulukap1 „K., Özdemir, B., Onus, N., (2015). "Determination of proper gamma radiation dose in mutation breeding in eggplant (Solanum melongena L.)" . Adv. in Env. and Agr. Sci. 149- 153.

Uslu, N., (1996). "M ${ }_{1}$ generasyonunda görülen mutagenik etkiler. Bitki Islahında Mutasyonların Ortaya Çıkarılması ve Kullanılması"kursu 27-31 Mayıs 1996, TAEK ANAEM Nükleer Tarım Bölümü Saray-Ankara.

Wang, P., Y. Zhang, L. Zhao, B. Mo, T. Luo., (2017). "Effect of gamma rays on Sophoradavidii and detection of DNA polymorphism through ISSR Marker". BioMed Res. Int.

Wi, S.G., B.Y. Chung, J.S. Kim, J.H. Kim, M.H. Baek, J.W. Lee, Y.S. Kim., (2007)." Effects of gamma irradiation on morphological changes and biological responses in plants."Micron, 38(6): 553-564.

Vaizoğulları, H. E., (2016)." Bazı yağlı tohumlu bitkilerde gama radyasyonun (Cs-137) M1 generasyonlarında oluşturduğu modifikasyonların fizyolojik özellikleri ile yağ verimine etkisinin belirlenmesi ve antimikrobiyal aktivitelerinin araştırılması" .Doktora tezi.Pamukkale Üniversitesi Fen Bilimleri Enstitüsü.

Verma, A.K., Sharma, S., Kakani, R.K., Meena, R.D., Choudhary, S., (2017). "Gamma radiation effects seed germination, plant growth and yield attributing characters of fennel (Foeniculum vulgare Mill.)". International Journal of Current Microbiology and Applied 6: 2448-2458.

Yazıcı, L., Çiçek, S., Küçüktaban, F., Çoban, M., Tuncel, N., (2016). "Nazilli 663 pamuk (Gossypiumhirsitum L.) çeşidinde farklı gama ışını dozlarının M1 bitkilerinde fide gelişimi üzerine etkisi ve uygun gama dozunun belirlenmesi". Tarla Bitkileri Merkez Araştırma Enstitüsü Dergisi, 25(Özel Say1-2), 88-93. 